\title{
PESCARIA PROBATÓRIA NO PROCESSO PENAL BRASILEIRO: O CONFLITO ENTRE O SISTEMA ACUSATÓRIO E OS PODERES INSTRUTÓRIOS DO JUIZ
}

\section{FISHING EXPEDITION AT BRAZILIAN CRIMINAL PROCESS: THE CONFLICT BETWEEN ACCUSATORY SYSTEM AND INSTRUCTIONAL POWERS}

RESUMO: Ultimamente, com o propósito de eliminar o anacronismo entre o código processual de 1941 e a Constituição Federal Brasileira de 1988, o processo penal brasileiro sofreu profundas reformas com a Lei $\mathrm{n}^{\circ}$ 13.964/2019. Acontece que, enquanto o Código de Processo Penal é sancionado sob a égide autoritária do Estado Novo de Vargas, a Constituição do Brasil prevê um sistema acusatório no que concerne ao procedimento penal. Nada obstante, o sistema acusatório é regido pelo princípio dispositivo, em que o julgador é um mero espectador na produção probatória, que fica sob incumbência exclusiva das partes. Em que pese o que fora elencado e as positivas alterações na legislação processual penal, a jurisdição criminal persiste em violar as garantias processuais do acusado. Nesse sentido, emerge a prática do fishing expedition ou pescaria probatória, em que por intermédio de mandados genéricos se procura obter determinada prova em desfavor do réu penal. Registre-se que, por interpretação teleológica da Constituição, a prática é vedada, ainda que empregada pelos magistrados alhures. Conclui-se que o prognóstico é a violação do princípio da imparcialidade e da presunção de inocência, assim como de outras garantias processuais conferidas ao réu em procedimento penal. Em síntese, na presente pesquisa será arrolado como método de abordagem o dedutivo, discutindo as dessemelhanças entre o sistema acusatórios e os poderes instrutórios do juiz dentro do processo criminal. Por fim, como método de procedimento, utilizar-se-á o comparativo, transcrevendo o quadro histórico do processo penal brasileiro e as distinções entre o sistema acusatório e o sistema inquisitivo.

Palavras-chave: Sistema acusatório; Pescaria probatória; Processo Penal brasileiro.

ABSTRACT: Lately, in order to eliminate the anachronism between the 1941 procedural code and the 1988 Brazilian Federal Constitution, the Brazilian criminal process has undergone profound reforms with Law $\mathrm{n}^{\circ}$ 13.964 / 2019. It so happens that, while the Penal Procedure Code is sanctioned under the authoritarian rule of the New State of Vargas, the Constitution of Brazil provides for an accusatory system with regard to criminal proceedings. However, the accusatory system is governed by the device principle, in which the judge is a mere spectator in the evidential production, which is the exclusive responsibility of the parties. Despite what was listed and the positive changes in criminal procedural law, criminal jurisdiction persists in violating the procedural guarantees of the accused. In this sense, the practice of fishing expedition emerges, in which, 
through generic warrants, one seeks to obtain certain evidence to the detriment of the criminal defendant. It should be noted that, by teleological interpretation of the Constitution, the practice is prohibited, even if employed by magistrates elsewhere. It is concluded that the prognosis is a violation of the principle of impartiality and the presumption of innocence, as well as other procedural guarantees given to the defendant in criminal proceedings. In summary, in this research the deductive approach will be listed, discussing the dissimilarities between the accusatory system and the judge's instructive powers within the criminal process. Finally, as procedural method, the comparative will be used, transcribing the historical picture of the Brazilian criminal process and the distinctions between the accusatory system and the inquisitive system.

Keywords: Accusatory system; Fishing expedition; Brazilian criminal procedure.

\section{INTRODUÇÃO}

Hodiernamente, embora formalmente tenha contornos democráticos, o processo penal brasileiro ainda atende às raízes autoritárias de outrora. Isto é, nada obstante a manifestação de uma nova Constituição desta vez, democrática e garantidora dos direitos fundamentais - não houve proposição de uma reforma aplausível na jurisdição criminal brasileira, que continua sob a égide de um código anacrônico.

Nesse sentido, enquanto a Constituição Federal de 1988 apresenta o princípio acusatório como norteador do procedimento penal no Brasil, e assim, divide as funções do juiz e do acusador, o Código de Processo Penal, por sua vez, sancionado anteriormente à redemocratização, ainda não oferece a guarida necessária para o devido processo penal, que exige o distanciamento do juiz da produção da prova. Ressaltese que desincumbido deste encargo, o juiz sentenciaria de modo plenamente imparcial.

Sob essa perspectiva, torna-se cada vez mais recorrente, a interferência prejudicial do julgador - o terceiro imparcial - na colheita da prova penal. Desta feita, por meio de mandados genéricos, o ator que deveria se manter alheio a oposição entre defesa e acusação - levando em consideração, o princípio da presunção de inocência como dever de tratamento - toma o lugar da acusação com "pescarias probatórias", tendo como único propósito incriminar o acusado - seja por revanchismo, seja pelo fomento da celeridade e diminuição da "burocracia" judicial.

Entrementes, essa pescaria probatória ou fishing expeditions podem ser significadas como diligências probatórias ausentes de uma "causa provável". Nesse sentido, "quem procura, procura algo", todavia, tal juízo cognitivo por parte do acusador macula a imparcialidade e a presunção de inocência do acusado, basilares se levado em conta o processo penal acusatório inserido na Constituição Federal. A reforma do CPP de 2019 - pela Lei n ${ }^{\circ} 13.964$ - trouxe avanços significativos, especialmente pela inserção da estrutura acusatória também pelo códex processual.

Sublinhe-se, que a pescaria de provas com o fim de incriminar alguém não é prática contemporânea, mas rechaçada desde a $04^{\mathrm{a}}$ emenda dos Estados Unidos, que suportaram os desmandos perpetrados pela 
Coroa Britânica antes da independência das treze colônias. Portanto, é visível que o fishing expedition é eivado de autoritarismo, tornando suspeita a atuação do magistrado.

Assim sendo, como método de abordagem, se arrolará o dedutivo, partindo das premissas no tocante ao tema, exempli gratia as raízes autoritárias do processo penal no Brasil, bem como a necessidade do alheamento do julgador. Logo, visar-se-á então a satisfação dos direitos humanos fundamentais - tanto das vítimas como dos acusados, levando em consideração o que os une: a condição de ser humano.

Outrossim, como método de procedimento, agregar-se-á o método comparativo. Isto posto, transcrever-se-á a origem do processo penal no Brasil, o simbolismo do princípio acusatório, e por fim, as comparações entre o processo inquisitivo e acusatório, com observância nas garantias fundamentais do réu em contenda penal.

\section{ORIGEM DO PROCESSO PENAL NO BRASIL}

Precipuamente, antes de iniciar as discussões acerca das garantias fundamentais do acusado em conflito com o mecanismo do fishing expedition - ainda utilizado pelos magistrados brasileiros, mesmo após a afirmação do princípio acusatório pela Constituição de 1988 -, torna-se premente traçar o escorço histórico do processo penal no Brasil.

Nesse sentido, parte-se dos primórdios da jurisdição penal no país, desde após a independência da Corte de Portugal, isto é, o início do Brasil Império. Desafortunadamente, o jus puniendi fora utilizado ao arrepio da imparcialidade inerente à um julgamento justo, como assevera Gomes (2007, p. 85):

Controlava-se a população pelo poder do perdão. O Rei contava com um ilimitado ius puniendi (assim como com o direito de perdoar). Enorme também (nessa época) foi a influência da Igreja: confundia-se o pecado com o delito (valeu-se também a Igreja do Direito penal para preservar o seu poder). Os crimes mais hediondos naquela época eram: lesa majestade humana (crime contra o rei) e lesa majestade divina (heresia, apostasia, blasfêmia, feitiçaria etc.) (GOMES. 2007, p. 85).

Em outros termos, a organização política do Estado brasileiro - influenciado pelo liberalismo político das revoluções burguesas na Europa - adotara, através da Carta Constitucional de 1824, o princípio da responsabilidade individual pelo cometimento dos delitos (BONAVIDADES; ANDRADE, 1991, p. 95). Outrossim, foram extintas as penas de açoites, torturas e qualquer outra pena cruel, ainda que isso não signifique o afastamento do mandonismo do seio público no país e muito menos, a adoção de um modelo processual penal comprometido em apartar as funções antagônicas de julgar e acusar (KARASCH, 2000).

Isto posto, o primeiro Código Criminal data de 1830, enquanto que o primeiro Código de Processo Criminal adveio em 1832. Embora respaldados pelos princípios iluministas, tais características não refletiriam penas proporcionais e procedimentos plenamente justos na esfera penal. Penas de morte, as galés e o banimento ainda se faziam presentes e se apresentavam como opções ao juiz criminal. 
Ainda pior, levando em conta a vigência do sistema escravagista, o Art. 60 do Código Criminal de 1830, ainda previa penas especiais quando o réu era escravo. Desse modo, se não se tratasse de pena capital ou às galés, a punição seria por açoites. Ressalte-se que ironicamente ainda se amenizava que não poderia ser ultrapassado o limite de cinquenta açoites por dia (IMPÉRIO DO BRASIL, 1830).

Tal cenário vigorou, em maior ou menor medida, até a primeira metade do Século XIX - vide que a cessação desse modelo não reflete o epílogo da mentalidade punitiva. Nesse período, os órgãos de justiça colocaram em prática um sistema de justiça penal manifestamente seletivo, mais apegado aos termos biológicos do crime, e também influenciado pelo racismo científico europeu. Isto é, "a estigmatização de camadas sociais destituídas com o rótulo de 'vadios' é um dado que percorre a história brasileira desde o período colonial" (FAUSTO, 2001, p. 50).

Sancionado no curso do período ditatorial do Estado Novo, por óbvio o Código de Processo Penal de 1941 não fora capaz de romper com a sanha punitiva da época. Ao contrário, a codificação processual penal somente exponenciou os traços totalitários, impulsionando sobremaneira as restrições das liberdades individuais. Sob esse ponto, interligando as características similares do CPP brasileiro com o Código Italiano de Rocco, Casara (2019, p. 153) assenta:

O que vigorava ao longo do processo criminal era uma "declaração (presunção) de não culpabilidade", uma postura que via o imputado (aquele a quem se atribui uma conduta criminosa) numa situação "neutra", em que ainda não podia ser tido como culpado, mas também não era visto como inocente (2019, p. 153).

Nessa acepção, a título de exemplo, demonstrando sua origem autoritária, o próprio Art. 596 do CPP - hoje revogado - aduzia que “a apelação de sentença absolutória não impedirá, que o réu seja posto imediatamente em liberdade, salvo nos processos por crime a que a lei comine pena de reclusão, no máximo, por tempo igual ou superior a oito anos" (BRASIL, 1941).

Em outros termos, mesmo que inexistisse o fato, o réu - agora inocentado - teria o gozo da sua liberdade retido. À luz do processo penal garantista, não somente uma violação ao princípio da presunção de inocência, como vilipêndio à dignidade da pessoa humana, que para Häberle é "a restrição" e a baliza do poder do Estado(HÄBERLE, 2016, p. 55).

Em 1988, em que pese a entrada à baila de uma Constituição Dirigente, pós-ditadura, as estirpes inquisitoriais não deixaram de cumprir com os seus propósitos, haja vista ainda presente - mesmo após a evolução dos direitos humanos e irradiação sobre as demais legislações - os desmandos e autoritarismos do Código de Processo Penal, inarredavelmente influenciado pelo Código de Processo Penal fascista italiano articulado por Vincenzo Manzini (COUTINHO, 2010, p. 2).

Dúvida irrazoável dizia respeito à questão acerca da recepção - ou não - do princípio da presunção de inocência pela Constituição novel, discutida pelos processualistas no momento da promulgação da Carta. Argumentava-se, à época, que o que fora pretendido pelo documento constitucional teria sido tão somente a presunção de não-culpabilidade. Tal embate doutrinário, foi devidamente rechaçado com a ratificação da 
Convenção Americana sobre Direitos Humanos de 1969, que alçou a presunção de inocência como pressuposto processual $^{1}$, assim, não cedendo espaços para o discurso autocrático no que tange a matéria principiológica (LOPES JÚNIOR, 2019, p. 99-100).

Contudo, ainda que avanços possam ser observados, especialmente em virtude da Constituição de 1988 e dos Tratados Internacionais de Direitos Humanos, a tese em prol de um Estado punitivo permanece preservada pelos magistrados brasileiros, que tendem a dissimular o princípio acusatório - que deveria ser o norte do processo penal contemporâneo no Brasil (LOPES JÚNIOR, 2012, p. 122).

Nesse sentido, rememore-se que nas lições de Choukr (2011, p. 32) “o eixo distintivo entre o modelo acusatório de processo e o inquisitivo se dá na gestão da prova”. Isto quer dizer em apertada síntese, que o juiz sob o sistema acusatório é um "mero espectador", devendo se manter alheio (o que Ferrajoli denomina de terzietá) à produção probatória. Se assim não o for, haverá uma "quebra de igualdade, do contraditório, da própria estrutura dialética do processo" que por conseguinte "fulminam a principal garantia da jurisdição, que é a imparcialidade do julgador" (LOPES JÚNIOR, 2007, p. 75).

Nada obstante o anacronismo do Código Processual Criminal, a observância das garantias fundamentais do acusado transcritas no Bloco de Constitucionalidade - que é imperativa - implica uma interpretação que visa suprimir as características inquisitoriais da legislação infraconstitucional, tornando a práxis da jurisdição penal harmoniosa com o devido processo legal e as garantias judiciais - insculpidas sob os vieses do garantismo penal (MIRANDA, 1993, p. 153).

Nesse ínterim, deve se afastar, a pari passu, a iniciativa probatória do magistrado, sob pena de provocado o aparecimento de um Estado Pós-Democrático em que "os direitos fundamentais passam a ser apontados como empecilhos à eficiência do Estado e à reprodução do capital” (CASARA, 2019, p. 145).

\section{DA OBSERVÂNCIA DAS GARANTIAS FUNDAMENTAIS DO ACUSADO: CONDIÇÕES PARA O PRINCÍPIOACUSATÓRIO NAINSTRUÇÃO PROBATÓRIA}

Como bem elucida Lopes Júnior (2019, p. 413) “forma é garantia e limite de poder" - mais do que isso, é tipicidade processual. Esta premissa se justifica pelo fato de que o processo penal tem o propósito de tutelar bens jurídicos distintos ao processo cível, melhor dizendo, interesses mais relevantes e dignos de guarida pelo Poder Público. Todavia, ressalte-se que a concepção supramencionada definitivamente não reflete a posição autoritária do Estado, tampouco do julgador. Em outras palavras:

O fundamento da legitimidade da jurisdição e da independência do Poder Judiciário está no reconhecimento da sua função de garantidor dos direitos fundamentais inseridos ou resultantes da Constituição. Nesse contexto, a função do juiz é atuar como garantidor dos direitos do acusado no processo penal (LOPES JÚNIOR, 2019, p. 59).

\footnotetext{
${ }^{1}$ Artigo 8. Garantias Judiciais [...] 2. Toda pessoa acusada de delito tem direito a que se presuma sua inocência enquanto não se comprove legalmente sua culpa (CONVENÇÃO AMERICANA SOBRE DIREITOS HUMANOS, 1969).
} 
Sob essa perspectiva, a figura do juiz não se confunde com a de um juiz-ator, ativo no processo judicial, ao contrário, o juiz do processo penal acusatório precisa estar para além dos interesses das partes. Não à toa, o princípio acusatório é indissociável da imparcialidade e do contraditório judicial. Resumem então, Lopes Jr. e Rosa (2018, p. 112) que “a garantia do devido processo legal substancial e da imparcialidade do julgador são frutos de evolução civilizatória que não podem ceder"'.

Nessa perspectiva, constata-se que de maneira democrática, não só é possível, como é legítimo que se puna, desde que não se esfacele as balizas do devido processo penal. De modo sincrético, Ferrajoli (2010, p. 312) define o garantismo penal:

\begin{abstract}
É a tutela daqueles valores fundamentais, cuja satisfação mesmo contra o interesse da maioria, constitui o objetivo justificante do direito penal, vale dizer, imunidade dos cidadãos contra a arbitrariedade das proibições e das punições, a defesa dos fracos mediante as regras do jogo iguais para todos, a dignidade da pessoa do imputado, e, consequentemente, a garantia de sua liberdade, inclusive por meio do respeito à sua verdade. É precisamente a garantia destes direitos fundamentais que torna aceitável por todos, inclusive pela minoria formada pelos réus e pelos imputados, o direito penal e o próprio princípio majoritário (FERRAJOLI, 2010, p. 312).
\end{abstract}

Significa dizer, portanto, que a prova a ser levada em consideração no processo judicial é tão somente aquela produzida em contraditório, haja vista que é pressuposto básico para satisfação do sistema acusatório. No sistema inquisitivo, por sua vez, Lopes Júnior (2019, p. 346) na esteira de Franco Cordero, indica que há "o primado das hipóteses sobre os fatos" que enseja no juiz um quadro paranoico na busca pela verdade real.

Desse modo, em tom de crítica, o que se vê no processo penal brasileiro é que ainda que se transcreva o princípio acusatório como orientador procedimental através da Constituição Federal, as legislações infraconstitucionais, bem como os integrantes do corpo judiciário persistem em reproduzir os comportamentos inquisitoriais de outras épocas. Em exempli gratia, Casara (2019, p. 195) assenta:

\begin{abstract}
Contrariando toda a jurisprudência anterior (e, após o julgamento do "Mensalão", a "tese" adotada foi novamente abandonada), entendeu-se que os acusados sem "foro por prerrogativa de função" - a Constituição estabelece que algumas pessoas que exercem função pública relevante devem ser julgadas por determinados órgãos jurisdicionais deveriam ser julgados diretamente pelo Supremo Tribunal Federal e com isso retirou-se de diversos acusados a garantia processual de fazer uso do sistema recursal. Em suma, a interpretação do STF, adotada para esse único caso, fez com que direitos e garantias dos acusados fossem afastados [...] afastando os órgãos judiciais previstos em lei para tanto, em clara violação casuística ao princípio constitucional do Juiz Natural (CASARA, 2019, p. 195).
\end{abstract}

Nessa altura, é necessário salientar a relação simbiótica entre o próprio conceito de prova e o seu propósito no convencimento psicológico do magistrado, nas lições de Aragoneses Alonso (1984, p. 251). O processo penal, em síntese, funcionaria dentro de uma finalidade retrospectiva, o que - por dedução lógica impossibilitaria o alcance da verdade real (LOPES JÚNIOR, 2019, p. 344).

Sob tais questionamentos, como definir o sistema adotado no processo penal brasileiro? Lopes 
Júnior $(2019$, p. 347) se propõe a responder tal inquirição afirmando a vigência de um modelo neoinquisitório. Assim, argumenta o eminente doutrinador, que dispositivos como o Art. 156 que permite a iniciativa probatória do juiz, bem como do Art. 83 acerca da prevenção, são inconciliáveis com o princípio dispositivo, em que o julgador estaria alheio à produção probatória.

Com ênfase no último artigo citado e questionado por Lopes Júnior, em petição apresentada pelo Conselho Federal da Ordem dos Advogados do Brasil como Amicus Curiae em defesa do juiz das garantias, citou-se o caso Piersack julgado pelo Tribunal Europeu de Direitos Humanos em 01/10/1982, vide:

\footnotetext{
No já citado julgamento do Caso Piersack vs. Bélgica, o Tribunal Europeu de Direitos Humanos afirmou que "todo juiz em relação ao qual possa haver razões legítimas para duvidar de sua imparcialidade deve abster-se de julgar o processo. O que está em jogo é a confiança que os tribunais devem inspirar nos cidadãos em uma sociedade democrática"; e concluiu: "é possível afirmar que o exercício prévio no processo de determinadas funções processuais pode provocar dúvidas de parcialidade" (grifos nossos) $)^{2}$.
}

O que se conclui é que muito embora a jurisprudência dos tribunais internacionais tenham evoluído sobre o recorte dos direitos humanos e das garantias fundamentais, no Brasil se caminha a passos curtos rumo à emancipação do princípio inquisitivo, à medida que se mantém práticas atrasadas, há muito tempo discriminadas pelas Cortes Regionais de Direitos Humanos. Possuindo certa similaridade com o caso Piersack vs. Bélgica, acima citado, em decisão do caso Herrera-Ulloa vs. Costa Rica, a Corte Interamericana de Direitos Humanos aduziu:

171. The right to be tried by an impartial judge or court is a fundamental guarantee of due process. In other words, the person on trial must have the guarantee that the judge or court presiding over his case brings to it the utmost objectivity. This way, courts inspire the necessary trust and confidence in the parties to the case and in the citizens of a democratic society (INTER-AMERICAN COURT OF HUMAN RIGHTS, 2004) ${ }^{3}$.

Nada obstante, repise que o atraso é fruto também do descompasso entre um código de processo penal autoritário e uma Carta Constitucional garantidora dos direitos fundamentais. Em suma, enquanto não são afirmadas a imparcialidade e a presunção de inocência - condições do sistema acusatório - o Brasil tende a somente a conservar este cenário teratológico.

\subsection{A "Pescaria Probatória" e os mandados genéricos: vale tudo pela verdade real?}

\footnotetext{
${ }^{2}$ OAB pede para ingressar em ADI e defende juiz das garantias. Revista Consultor Jurídico. Disponível em: https://www.conjur.com.br/2019-dez-31/oab-ingressar-adi-juiz-garantias. Acesso em: 03 out. 2020.

${ }^{3}$ 171. O direito de ser julgado por um juiz ou tribunal imparcial é fundamental garantia de devido processo. Em outras palavras, a pessoa em julgamento deve ter a garantia de que o juiz ou tribunal que preside seu caso traga a ele o máximo objetividade. Dessa forma, os tribunais inspiram a confiança necessária nas partes ao caso e aos cidadãos de uma sociedade democrática (Tradução nossa).
} 
Uma das práticas reiteradas pelo judiciário brasileiro - permitida (em parte) pela nebulosa classificação do sistema misto, adotado no Brasil - diz respeito à pescaria probatória, também originalmente denominada pela doutrina como fishing expedition. Consiste, então, na tomada de partido do magistrado, para além das balizas do processo penal democrático, seja de ofício ou à requerimento do Ministério Público, titular da ação penal.

Inicialmente, as diligências que ultrapassam os direitos fundamentais do acusado têm origem na busca pela verdade real e inconteste do fato jurídico penal. Entretanto, é possível ter a percepção exata de algo que aconteceu no passado, isto é, a verdade real? Lopes Júnior (2019, p. 372) contradiz a verdade real, esclarecendo que:

O mito da verdade real está intimamente relacionado com a estrutura do sistema inquisitório; com o "interesse público" (cláusula geral que serviu de argumento para as maiores atrocidades); com sistemas políticos autoritários; com a busca de uma "verdade" a qualquer custo (chegando a legitimar a tortura em determinados momentos históricos); e com a figura do juiz-ator (inquisidor) (LOPES JÚNIOR, 2019, p. 372).

Eis que Ferrajoli (2010, p. 44) expõe como alternativa ao autoritarismo, a verdade processual ou substancial. Ou seja, o que se pretende alcançar nessa linha é a verdade obtida mediante o respeito ao procedimento em contraditório, portanto, uma verdade aproximativa e contingencial. $\mathrm{O}$ eminente doutrinador ainda acrescenta ao pensamento ora citado, o destaque que na esteira da teoria da relatividade de Einstein, todo conhecimento é datado e tem prazo de validade, e em sendo assim, a verdade real seria inalcançável(LOPES JÚNIOR, 2019, p. 375).

Ademais, pontue-se que não é contemporânea à história a expedição de mandados aleatórios, sem objeto especificado. Na colônia britânica na América do Norte, já eram expedidos os writs of assistance, em significados práticos símiles à pescaria probatória (MACIEL, 2019, p. 53). Insatisfeitos, após a independência, os americanos, que viveram a posição autocrática do Estado colonizador, impuseram na sua $04^{\mathrm{a}}$ emenda o que se segue:

The right of the people to be secure in their persons, houses, papers, and effects, against unreasonable searches and seizures, shall not be violated, and no Warrants shall issue, but upon probable cause, supported by Oath or affirmation, and particularly describing the place to be searched, and the persons or things to be seized ${ }^{4}$ (CONSTITUTION OF THE UNITED STATES, 1789).

Embora a experiência americana já convencione às ilegalidades dos mandados genéricos, justificase os meios empregados pelos fins pretendidos ainda na busca pela verdade real e se amplia a discricionariedade do julgador penal - mesmo que tal concepção seja manifestamente incompatível nos

\footnotetext{
${ }^{4} \mathrm{O}$ direito das pessoas de estarem seguras em suas pessoas, casas, papéis e pertences, contra buscas e apreensões irracionais, não deve ser violado e nenhum mandado deve ser emitido, mas por causa provável, apoiado por juramento ou afirmação, e particularmente descrevendo o lugar a ser revistado e as pessoas ou coisas a serem apreendidas (Tradução nossa).
} 
termos da Constituição Brasileira vigente (GRINOVER; GOMES FILHO; FERANDES, 2011, p. 125). Assim, em que pese os objetivos elencados como fundamentadores de uma jurisdição democrática, mandados genéricos e com objeto amplo continuam sendo uma realidade no procedimento criminal brasileiro. Sob esse aspecto, Binder (2002, p. 188) alerta:

O mandado de busca deve sempre conter os fins e os motivos de sua expedição, para que não se dê ao executor um cheque em branco, possibilitando verdadeiras devassas na intimidade alheia [...] a ordem de busca não pode ser genérica, quanto ao tempo ou quanto ao lugar, deve estar circunscrita temporalmente (isso não significa que deva ser expedida necessariamente para um dia determinado, porém não pode ser uma ordem 'aberta', com validade permanente); e deve determinar com precisão - e expressamente - o local que pode e deve ser revistado (BINDER, 2002, p. 188).

Por outro lado, partidários da pescaria probatória a justificam pela "causa provável”, ainda que a referida causa não coadune com mandados genéricos, suposições vagas e excessivamente intervenientes. Como acima discutido, o sistema acusatório prevê a estrita observância das garantias fundamentais do acusado e dos limites constitucionais, mormente após a inclusão do Art. $3^{\circ}$-A pela Lei 13.964/20195 (ROSA, 2020,p. 322).

Não à toa, cabe ao julgador da querela fazer valer o devido processo legal substancial, assim, oferecendo às partes oportunidades equânimes de participação no jogo processual, mas também balizando a atuação da acusação pelos direitos humanos conferidos ao réu penal. Nesse ínterim, Rosa (2020, p. 326) leciona:

\begin{abstract}
A ampliação das garantias contra o arbítrio do Estado é decorrência da compreensão autêntica do devido processo legal substancial [...] No processo penal, diante do princípio da legalidade, a aplicação deve ser favorável ao acusado e jamais em nome da coletividade, especialmente em matéria probatória e de restrição de direitos fundamentais (ROSA, 2020, p. 326).
\end{abstract}

No entanto, repise que há um disparate entre a ontologia (ser) e a deontologia (dever ser), como pode ser percebido alhures. Embora a lei preveja a produção probatória em contraditório judicial e que as formalidades legais devem ser estritamente observadas - no intuito de evitar a discricionariedade -, a pretensão punitiva, também notadamente pela pressão midiática, insurge rompendo barreiras e mitigando direitos inalienáveis:

O processo penal do espetáculo objetiva “esculachar" qualquer um dos indiciados e/ou acusados e, ainda que promova a responsabilização aparente da classe vip, traz consigo a espetacularização, com maior vigor, dos crimes que estão próximos do sujeito (LOPES JÚNIOR; ROSA, p. 68).

\footnotetext{
${ }^{5}$ Art. $3^{\circ}$-A. O processo penal terá estrutura acusatória, vedadas a iniciativa do juiz na fase de investigação e a substituição da atuação probatória do órgão de acusação (BRASIL, 2019).
} 
Outrossim, a imparcialidade do magistrado é conditio sine qua non para o princípio acusatório e resta ausente quando o juiz é contaminado por pré-juízos sobre o acusado em pescarias probatórias inespecíficas (LOPES JÚNIOR, ROSA, p. 108). Com essa percepção, a postura medieval deve ser sobrepujada, fazendo prevalecer o juiz-espectador, que decide com "estranheza" e principalmente alicerçado pelos corolários constitucionais. Aqui, valoriza-se o processo como "caminho necessário" e também como fator intransigível, sob pena de um julgamento autoritário (Princípio da Necessidade - Gomez Orbaneja). Argumentando pela impossibilidade da generalidade dos mandados, a Supremo Tribunal Federal, em exame de Habeas Corpus, expôs:

Penal e Processual Penal. 2. Busca e apreensão em local distinto do definido no mandado judicial. 3. Autorização de meio de investigação em endereços de pessoa jurídica, mas o ato foi realizado na casa de pessoas físicas não elencadas no rol. 4. Ilegalidade que impõe o reconhecimento da ilicitude da prova. 5. Ordem concedida para declarar a ilicitude dos elementos probatórios obtidos na busca e apreensão realizada no domicílio das pessoas físicas e suas derivadas, nos termos do acórdão (Habeas Corpus 163461, Relator(a): Gilmar Mendes, Segunda Turma, julgado em 05/02/2019, DJ: $31 / 07 / 2020)$.

Nos termos de Foucault (2014, p. 207), o que se busca com mandados como este - rechaçados pelo Supremo Tribunal Federal - é nada mais que, "uma vigilância permanente, exaustiva, onipresente, capaz de tornar tudo visível, mas com a condição de se tornar ela mesma invisível".

Corrobora o defendido, o mencionado pelo Ministro Celso de Mello: “A lei é clara. O Código de Processo Penal, em seu artigo 243, exige que do mandado de busca e apreensão conste, sempre que possível, o local objeto da busca" (MELLO, 2018) ${ }^{6}$. Novamente, a busca pela verdade real não pode se fazer valer perante as liberdades individuais de quem quer seja.

Contextualizando exemplos do fishing expedition, nada obstante o entendimento consolidado do $\mathrm{STF}$, a mentalidade inquisitiva do judiciário pode ser provada pelos acórdãos denunciando a prática destas pescarias probatórias - que indicam a ocorrência do mecanismo nos juízos de instâncias inferiores -, vide o Agravo Regimental no Inquérito 2245/MG e o Habeas Corpus 137.828/RS.

Atente-se, contudo, que na própria determinação de um membro - o Ministro Alexandre de Moraes em decisão, pôde ser vislumbrada a expedição de mandado genérico, em específico no Inquérito $4.781^{7}$, assim, nem mesmo o Supremo, guardião da ordem democrática constitucional, extirpou o medieval desejo de punir-a todo custo, se necessário.

À guisa de conclusão, esclarece-se que não vale tudo pela verdade real. Esta funciona tão somente como delimitadora das garantias fundamentais. Ao contrário, a verdade processual, formal ou substancial, construída por meio do procedimento em contraditório judicial é aquela que se deve dar guarida,

\footnotetext{
${ }^{6}$ Mandado de busca genérico contraria presunção de inocência, diz Celso de Mello. In: Consultor Jurídico. Disponível em: https://www.conjur.com.br/2018-fev-21/mandado-busca-generico-viola-presuncao-inocencia-celso. Acesso em: 10 out. 2020.

${ }_{7}$ Mandado genérico de Moraes é proibido pelo próprio STF. In: Migalhas. Disponível em: https://migalhas.uol.com.br/quentes/300495/mandado-generico-de-moraes-e-proibido-pelo-proprio-stf. Acesso em: 10 out. 2020.
} 
especialmente por ser submissa às inerentes garantias processuais do acusado. Frise-se que pelo bem da democracia processual, o magistrado não tem a missão de revelar a verdade, todavia, as partes que são as responsáveis pela captura psíquica do juiz(LOPES JÚNIOR, 2019, p. 376).

\section{CONSIDERAÇÕES FINAIS}

Ao longo da pesquisa, foram analisados, de maneira exauriente, os conflitos existentes entre o sistema acusatório - transcrito na Constituição Federal de 1988 e no Art. $3^{\circ}$-A do Código de Processo Penal-e os poderes instrutórios do magistrado, ainda insistentemente empregados. Isto posto, previamente, se trouxe a discussão as raízes do processo penal no Brasil, fincado sob o solo autoritário do Estado Novo de Vargas e marcadamente influenciado pelo Código Fascista de Rocco.

Porquanto, as experiências totalitárias não olvidaram de alertar para a sociedade global, aquele que deveria ser o princípio central das legislações: a dignidade da pessoa humana. Como centro axiológico, a dignidade humana funciona como a racionalização e a baliza do poder político.

Tal pressuposto implica dizer que a condição humana é inalienável, seja vítima ou acusado em processo penal. Logo, a este último, também são asseguradas garantias fundamentais que devem nortear a atividade do julgador. Nada obstante, a manifestação destas garantias configura como condição para expressão do sistema acusatório, em que divididos estão os papéis entre julgador e acusador.

Torna cristalino que no Brasil, entretanto, a sanha punitiva continua a exercer seu papel se esforçando em prol da mitigação das garantias processuais. Esses agentes - não somente a mídia, como os próprios integrantes do corpo judiciário - reclamam por uma maior celeridade do processo penal, sob pena de impunidade dos sujeitos “desviantes".

Esquece-se, portanto, que o Processo Penal é lastreado por princípios distintos ao procedimento cível e que, por óbvio, bens jurídicos mais relevantes são tutelados. Nessa perspectiva, o compromisso do julgador é tão somente zelar pelas garantias processuais do réu penal, fundamentando sua sentença exclusivamente pela prova obtida em contraditório judicial.

No que concerne ao objeto da pesquisa - a pescaria probatória -, observa-se que mesmo com a evolução na legislação nacional e internacional na matéria de direitos humanos, a imparcialidade do julgador permanece sendo discutida nos tribunais, o que denota, a contrario sensu, que a estabilização de um julgamento completamente justo e imparcial ainda é uma quimera no país.

Digno de nota, que a imparcialidade do juiz pressupõe tanto um aspecto objetivo, como também subjetivo. Isto implica dizer que mais do que ser conscientemente imparcial, o magistrado deve também parecer estar "alheio" ao processo. Espera-se de um julgador, no processo penal garantidor de direitos, exclusivamente que ele cumpra com autonomia os pressupostos fundamentais para o julgamento justo mesmo que contra a vontade da sociedade, impregnada pelo autoritarismo. 


\section{REFERÊNCIAS BIBLIOGRÁFICAS:}

ARAGONESES ALONSO, Pedro. Instituciones de Derecho Procesal Penal. 5.ed. Madrid: Editorial Rubí Artes Gráficas, 1984.

BINDER, Alberto M. Introdução ao Direito Processual Penal. Trad: Fernando Zani. Rio de Janeiro: Lumen Juris, 2003.

BRASIL. Decreto-Lei no 3.689, de 03 de outubro de 1941. Código de Processo Penal. Disponível em: http://www.planalto.gov.br/ccivil_03/decreto-lei/del3689compilado.htm. Acesso em: 03 out. 2020.

BRASIL. Lei n 13.964 , de 24 de dezembro de 2019. Aperfeiçoa a legislação penal e processual penal. Disponível em: http://www.planalto.gov.br/ccivil_03/_ato2019-2022/2019/lei/L13964.htm. Acesso em: 03 out. 2020 .

BRASIL. Supremo Tribunal Federal. Agravo Regimental no Inquérito 2245. Relator: Min. Joaquim Barbosa. Brasília, 09 de novembrode 2007 . Disponível e m: $\mathrm{http}$ //stf.jus.br/portal/processo/verProcessoAndamento.asp?numero=2245\&classe=InqAgR\&codigoClass $\mathrm{e}=0 \&$ origem $=J U R \&$ recurso $=0 \&$ tipoJulgamento=M. Acesso em: 10 out. 2020.

BRASIL. Supremo Tribunal Federal. Inquérito n⿳0 4781. Relator: Min. Alexandre de Moraes. Brasília, 12 de abril de 2019. Disponível em: https://migalhas.uol.com.br/arquivos/2019/4/art20190416-10.pdf. Acesso em: 10 out. 2020 .

BRASIL. Supremo Tribunal Federal. Habeas Corpus n 163461. Rel. Min. Gilmar Mendes. Brasília, 31 de

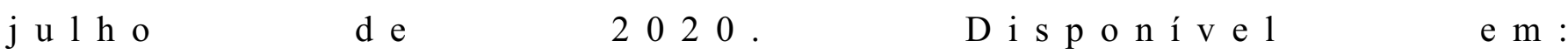
http://redir.stf.jus.br/paginadorpub/paginador.jsp?docTP=TP\&docID=753368425. Acesso em: 09 out. 2020.

BRASIL. Supremo Tribunal Federal. Habeas Corpus n 137828. Rel. Min. Dias Toffoli. Brasília, 16 de d e $\mathrm{z}$ e $\mathrm{m} \mathrm{b}$ r o d e $\quad 2016$. D i s p o n í v e 1 e $\mathrm{m}$ : http://stf.jus.br/portal/jurisprudencia/visualizarEmenta.asp?s1=000311556\&base=baseMonocratic as. Acesso em: 10 out. 2020.

BONAVIDES, Paulo; e ANDRADE, Paes. História Constitucional do Brasil. 3. ed, Rio de Janeiro: Paz e Terra, 1991.

CASARA, Rubens. Estado Pós-Democrático: Neobscurantismo e gestão dos indesejáveis. 5.ed. Rio de Janeiro: Civilização Brasileira, 2019.

C ON T I T U T O N OF UN T E D TATES DE 1789 . Disponível e m: https://www.senate.gov/civics/constitution_item/constitution.htm. Acesso em: 10 out. 2020.

COUTINHO, Jacinto Nelson de Miranda. Legibus Solutio: a sensação dos que são contra a reforma global do CPP. Boletim IBCCRIM, n. 210, v. 18, 2010.p. 2. 
COUTINHO, Jacinto Nelson de Miranda; LOPES JÚNIOR, Aury; ROSA; Alexandre Morais da. Delação Premiada no Limite: A Controvertida Justiça Negocial Made in Brazil. Florianópolis: EMais, 2018.

CHOUKR, Fauzi Hassan. Código de Processo Penal - Comentários Consolidados e Crítica Jurisprudencial. Rio de Janeiro: Lumen Juris, 2011.

FAUSTO, Boris. Crime e Cotidiano: A criminalidade em São Paulo (1880-1924). 2.ed. São Paulo: EDUSP, 2001.

FERRAJOLI, Luigi. Direito e Razão: Teoria do Garantismo Penal. $3^{\text {a }}$ edição. Editora: Revista dos Tribunais, 2010.

FOUCAULT, Michel. Vigiar e Punir: Nascimento da prisão. 42.ed. Rio de Janeiro: Vozes, 2014.

GRINOVER, Ada Pellegrini; GOMES FILHO, Antônio Magalhães; FERNANDES, Antonio Scarance. As nulidades no processo penal. 12. ed. São Paulo: Revista dos Tribunais, 2011.

HÄBERLE, Peter. Textos clássicos na vida das Constituições. São Paulo: Saraiva, 2016.

IMPÉRIO DO BRASIL. Lei de 16 de dezembro de 1830. Manda executar o Codigo Criminal. Disponível em: http://www.planalto.gov.br/ccivil_03/leis/lim/lim-16-12-1830.htm. Acesso em: 19 set. 2020.

KARASCH, Mary. A vida dos escravos no Rio de Janeiro (1808-1850). São Paulo: Companhia das Letras, 2000 .

LOPES JÚNIOR, Aury. Direito Processual Penal: e sua conformidade Constitucional. 9. ed. São Paulo: Saraiva, 2012.

LOPES JÚNIOR, Aury. Direito Processual Penal. 16.ed. São Paulo: Saraiva, 2019.

Mandado genérico de Moraes é proibido pelo próprio STF. In: Migalhas. Disponível em: https://migalhas.uol.com.br/quentes/300495/mandado-generico-de-moraes-e-proibido-pelo-proprio-stf. Acesso em: 10 out. 2020.

MIRANDA, Jorge. Manual de Direito Constitucional. 2a ed. Coimbra: Coimbra. 1993.

OAB pede para ingressar em ADI e defende juiz das garantias. Revista Consultor Jurídico. Disponível em: https://www.conjur.com.br/2019-dez-31/oab-ingressar-adi-juiz-garantias. Acesso em: 03 out. 2020.

ORGANIZAÇÃO DOS ESTADOS AMERICANOS. Corte Interamericana de Direitos Humanos (IDH). Caso Herrera Ulloa v. Costa Rica. Corte Interamericana de Derechos Humanos, San José, 2 de julho de 2004. Disponível em: http://corteidh.or.cr/docs/casos/articulos/seriec_107_ing.pdf. Acesso em: 11 nov. 2020.

ROSA, Alexandre Morais da. Guia do Processo Penal conforme à Teoria dos Jogos. 6.ed. Florianópolis: Emais, 2020. 